\title{
Regional specialization and geographic concentration: experiences from Slovak industry
}

Abstract

This paper attempts to indicate changes in industry during the period of economic restructuring and European integration in Slovakia in the regional and sectoral contexts. The concepts of geographic concentration and regional specialization are used in order to achieve the envisaged aims. Based on the relationship between the change in the specialization index and the change in the number of companies in three size categories, the main aim is to show the strategies used in the transformation of the regional industrial structure. It is expected that the largest category of industrial companies, those with 250 or more employees, will be a significant factor in explaining the changes in regional specialization. The main output will be a graphic model of transformation strategies and the identification of regional industrial types.

Keywords

Industry sector - regional specialization - geographic concentration • Herfindahl-Hirschman index • Slovak regions

(C) University of Warsaw - Faculty of Geography and Regional Studies

\author{
Lehocký Filip', Rusnák Jaroslav² \\ 'Department of Human Geography and \\ Demography, Faculty of Natural Sciences, \\ Comenius University in Bratislava, Slovakia \\ e-mail: lehocky@fns.uniba.sk \\ Department of Human Geography and \\ Demography, Faculty of Natural Sciences, \\ Comenius University in Bratislava, Slovakia \\ e-mail: rusnak@fns.uniba.sk \\ Received: 30 November 2015 \\ Accepted: 28 April 2016
}

Introduction

The fundamental economic changes that occurred in Central and Eastern Europe after 1989 have been discussed from various points of view. The first of these approaches deals with the political economy of post-socialist transformation (Pickles \& Smith 1998). The political economy approach essentially criticises the modernisation theory of transition and suggests an alternative concept of post-socialist transformation (Sokol 2001, Pavlínek 2002, Morvay 2005, Rusnák \& Korec 2013). Transformation of the economy and industry sector has led to the development of specific features influenced by various forms of privatization, deregulation and liberalization, deepening European integration and regional policies at various levels (Mládek 1995, Smith 1998, Parysek \& Stryjakiewicz 2000, Osiński 2004, Wandel 2010). In the context of transforming countries in Central and Eastern Europe, Lane and Myant (2007) and Nölke and Vliegenthart (2009) distinguish between various local varieties of capitalism. Other studies have highlighted concepts such as recombined capitalism and the path dependency approach (Stark \& Brurszt, 1998), dual economy (Baláž et al., 2007), and embedded neoliberalism or corporative capitalism (Bohle \& Greskovits 2012).

Secondly, there is the empirical analytical approach, which is related to the new economic geography (Krugman 1991). While traditional trade theory is based on comparative advantage, the new economic geography also stresses the role of domestic market effects and transport costs. The new economic geography emanates from the assumptions of imperfect (monopolistic) competition, which imply increasing returns to scale. If increasing returns lead the company to concentrate its production in a few places, then the company seeks the locations with the highest market potential, where demand is high and transport costs are low. The domestic market effect implies some degree of regional specialization, since larger regions tend to be net exporters of manufactured goods and smaller regions tend to be net exporters of agricultural goods (Fujita \& Thisse 2009).

With regards to the European economic integration, the core-periphery model considers the mobility of both goods and capital, as well as the variability of the labour market across the regions (Fujita et al. 1999). Some empirical studies point out the increasing concentration of the manufacturing sector (e.g. textiles) as a result of the delocalization of economic activities towards southern Europe (Hallet 2000, Brulhart \& Traeger, 2005). In this context, Traistaru et al. (2002) stress that the delocalization of industrial activities related to the enlargement of the EU led to increasing regional specialization in Bulgaria and Romania, while contributing to the decrease of regional specialization in Estonia.

The delocalization of economic activities is influenced by technology as well as the by labour demand of a particular sector. Ezcurra et al. (2006) claim that the results show the most highly concentrated sector to be the metals industry, probably because of the existing location patterns of natural resources. On the other hand, the most widely dispersed activities tend to be low-tech industries in which economies of scale are less relevant and their activities are more locally related, such as the food, beverage and tobacco industry.

Hallet (2000) claims that the regional specialization of the EU15, expressed in GDP, decreased slightly from about $14 \%$ in 1980 to below 13\% in 1995. Between 1980 and 1995, only 34 regions became more specialized, while 85 regions became 
less specialized. Brulhard and Traeger (2005) came to the conclusion that the European manufacturing sector is slowly becoming more geographically concentrated in terms of the spatial distribution of total employment (geographic concentration); however, with respect to physical space, manufacturing concentration is decreasing (regional specialisation). In other words, while geographic concentration slightly increased, regional specialization fell from $26 \%$ to $13 \%$ between 1975 and 2000 .

Other empirical evidence (based on production data) shows that specialization increased in the 1980s and 1990s in the EU member states. For example, Midelfart and Knarvik et al. (2003) highlighted the increasing specialization of EU countries between 1970 and 1997. A number of industries that were initially spatially dispersed became more concentrated. These were mainly slow growing and unskilled, labour-intensive industries whose relative contraction was accompanied by spatial concentration, usually in peripheral low wage economies.

The diversity of geographic concentration and economic specialization is also emphasised by Aiginger and Davies (2004), who claim that regional specialization increased and the concentration of industries decreased in the EU member states during the 1990s. However, they argue that specialization in the structures of individual countries (regions) does not necessarily mean that industries will become more geographically concentrated.

Bearing in mind these contradictions, post-socialist transformation of the industrial sector is related to a specific process of adjustment of the economy. In accordance with Ženka et al. (2015), the authors believe that the results of empirical observations of spatial concentration in the American or Western European industry sectors cannot be directly applied in the specific context of post-socialist countries. In this context, postsocialist countries can be considered a suitable research subject.

As stressed by Konyova and Bartova (2013), between 1995 and 2010 there was a continuous increase in sectoral concentration and decrease in regional specialization even in Slovakia. On the other hand, research conducted by Rehák and Štofka (2011) points out a slightly increase in specialization between 1997 and 2008, although this process was different in specific sectors. Last but not least, Melišek (2008) suggests that there was no recognisable increase in the specialization index, nor in the concentration index, in the V4 countries. Moreover, mean industry values were highest in both indices for Slovakia, compared to the other V4 countries. The above mentioned papers share one common disadvantage, which is their use of the NUTS III level as the basic analytical unit. Vojtková and Kvetan (2011) claim that the changing structure of industrial production is related to the strengthening of technologically more demanding sectors, while at the same time, tendencies for growth in Slovakia's industrial production are most strongly influenced by medium-intensive technologies.

The discrepancies in the results of regional specialization and geographic concentration in the context of regional development are influenced by various aspects. Following many authors (Hallet 2000, Midelfart Knarvik et al. 2003, Beaudry \& Schiffauerova 2009, Ženka et al. 2015), several points can be emphasized:

- $\quad$ spatial scale ("size effect")

- dimension of time (from five to twenty-five years)

- variables are mostly economical (production, GDP, employment or trade in the manufacturing sector, taken from the national Eurostat dataset)

- $\quad$ measurement techniques

- historical legacy (over-industrialization of post-socialist regions)

- $\quad$ sociocultural context (institution, embeddedness, mutual trust)
The present paper will focus further on the transformation processes of Slovak industry between 1997 and 2007. The concepts used include geographic concentration and regional specialization applicable to spatial distribution, intensity and industrial activity structure. Based on the relationship between the change in the specialization index and the change in the number of companies in three size categories, the main aim is to describe the strategies used in the transformation of the regional industrial structure. The authors expect to find an increase in the geographic concentration of industrial sectors and a decrease in regional specialization. It is also expected that changes in specialization will be explained by the change in the number of companies in the size category of 250 or more employees. The main output will be a graphic model of transformation strategies and the identification of regional industrial types.

\section{Research methodology and database}

Regional specialization describes the distribution of sectoral shares in the overall regional economy compared to the whole country, whereas the geographical concentration of a specific industry reflects the distribution of its shares in different regions. A region is considered to be highly specialized if a certain industrial sector has a dominant share in the economy of the region. If there are several industrial sectors in the region, consequently, this region is not specialized. Highly concentrated sectors occur in a small number of regions, while sectors with a lower concentration are divided more proportionally among the regions.

The majority of studies exploring the spatial distribution of economic (industrial) activities use the Herfindahl-Hirschman index, the Krugman specialization index and the Hoover-Balassa coefficient. Each of these indices has its own strengths and weaknesses. The present study uses the Herfindahl-Hirschman index, which represents the absolute level of concentration or specialization. The Herfindahl-Hirschman index uses the following formula:

$$
\begin{aligned}
& H H I_{j}^{k}=\sum_{i j}^{n}\left(g_{i j}^{k}\right)^{2} ; H H I_{i}^{S}=\sum_{i j}^{m}\left(g_{i j}^{s}\right)^{2} ; \\
& g_{i j}^{k}=\frac{X_{i j}}{\sum_{i=1}^{n} X_{i j}}=\frac{X_{i j}}{X_{j}} ; g_{i j}^{S}=\frac{X_{i j}}{\sum_{j=1}^{m} X_{i j}}=\frac{X_{i j}}{X_{i}}
\end{aligned}
$$

where, $H H I_{j}^{c}$ is the Herfindahl-Hirschman concentration index and $H H I_{i}^{S}$ is the Herfindahl-Hirschman specialization index; $i$ is the region and $j$ is the sector; $X$ is the number of employees; $X_{i j}$ is the number of employees in region $i$ in sector $j ; X_{j}$ is the number of employees in sector $j ; X_{i}$ is the number of employees in region $i ; g_{i j}^{k}$ is the share of region $i$ in the overall value of the country in sector $j ; g_{i j}^{S}$ is the share of sector $j$ in the overall value of region $i$. The Herfindahl-Hirschman index reaches the maximum value of 1 if sector $j$ is concentrated in one region $i$ only (sectoral concentration) or if there is only one sector $j$ represented in region $i$ (regional specialization).

The index has been used especially in the evaluation of the level and impact of the concentration and specialization of companies (branches) with regards to their competitiveness within the free market economy. A low value for a company on the index of specialization/concentration (0.1 or lower) indicates perfect competition. Values above 0.25 indicate imperfect (monopoly) competition. Analogically, if the concentration reaches values below 0.01, it expresses dispersion of the structure of the sector; values between 0.01 and 0.1 express poor sectoral concentration and values between 0.1 and 0.25 signal medium concentration. All values above 0.25 suggest highly concentrated sectors. The source database was created in cooperation with the Statistical Office of the Slovak Republic. The authors used three digit 
classifications and identified 29 sectors according to the Sectors Branch of the Statistical Classification of Economic Activities (OKEC 10-41). This classification was valid until 31.12.2007 and was replaced by NACE from 01.01.2008.

\section{Dependent variable}

Change in regional specialization between 1997 and 2007, as interpreted by the Herfindahl-Hirschman specialization index, was chosen as the dependent variable. The benchmark year was 1997. If the value of change on the specialization index was higher than 1.0, then regional specialization increased between 1997 and 2007, while if the value of change on the specialization index was below 1.0, then regional specialization decreased.

\section{Independent variable}

The independent variables were the initial level of the specialization index in 1997 and the size category of the companies. The Statistical Office of the Slovak Republic provided three size categories: 0 - 49 employees, 50 - 249 employees and 250 or more employees. Tables 2 and 3 show differences in the number of companies between 1997 and 2007, according to the above mentioned categories.

Table 4 and Figure 1 present the relative change in the number of companies according to the above mentioned categories. Again, the benchmark year was 1997. Regression analysis is used to address the following question: Which of the size categories has the most significant impact on the change in regional specialization? In other words, an attempt is made to find out how the specialization of the region is moulded by the presence of the various companies, in terms of their size. Table 1 shows all of the variables used in the analysis, with their basic descriptions.

Functional urban regions (FUR) were chosen as the referential spatial units. FURs represent a specific type of functional (nodal) region based on criteria related to the spatial interactions between cities and their surrounding areas (building on the core-periphery model) (Bezák, 2000).
Results

The most significant decrease in the number of companies was recorded in the size category of 250 or more employees, unlike the smallest size category, where the highest increase was noticed. In terms of the variability of industrial companies, representation of the smaller companies in the region is more variable than that of their larger counterparts; however, in the latter category there is an increase of variability over time.

\section{Geographic Concentration}

Table 2 analyses industrial sector concentration and the difference in the number of companies according to size categories. First of all, it must be noted that there are differences in the level of geographic concentration among industrial sectors. This is documented by the high variation coefficient which increased between 1997 (coefficient of variation 118.3\%) and $2007(128.4 \%)$. The highest values of the concentration index occur in resource-intensive industries, which are bound to raw material resources, the technological environment, and infrastructure (code 10,11, 13). Low concentration indices were found in the sectors of food production and metal production, which either cover basic local demand or have the position of subcontracting partners for the automotive industry.

Another important remark is related to the fact that, in both cross-sectional periods, the proportion of highly concentrated sectors did not change ( $20 \%$ of sectors had a concentration index above 0.25 ). Concentration decreased significantly mainly in the labour-intensive sectors of rubber and leather manufacturing. An increase in concentration can be seen in traditional (mature) sectors (e.g. metal ores, coal mining and petroleum) and new distribution sectors (e.g. distribution of electricity, gas and water or recycling of secondary raw materials).

Table 2 also shows the difference in the number of companies in all size categories in the context of the individual industrial branches. Several companies with more than 250 employees, which used to be a symbol of certain industrial sectors, collapsed in the period of restructuring. More than $70 \%$ of industrial

Table 1. Descriptive statistics for variables

\begin{tabular}{|c|c|c|c|c|c|c|c|}
\hline Indicator & Abbreviation & Average & Median & Minimum & Maximum & $\begin{array}{c}\text { Variation } \\
\text { margin }\end{array}$ & $\begin{array}{c}\text { Coefficient of } \\
\text { variation }\end{array}$ \\
\hline $\begin{array}{c}\text { Specialization index } \\
(1997)\end{array}$ & SI97 & 0.28 & 0.25 & 0.1 & 0.71 & 0.61 & 49.09 \\
\hline $\begin{array}{c}\text { Specialization index } \\
(2007)\end{array}$ & SI07 & 0.25 & 0.22 & 0.1 & 0.55 & 0.45 & 46.94 \\
\hline $\begin{array}{c}\text { Change in the number } \\
\text { of companies 0-49 } \\
(1997-2007)\end{array}$ & NoF 49 07/97 & 1.39 & 1.39 & 0.91 & 2.06 & 1.16 & 19.85 \\
\hline $\begin{array}{c}\text { Change in the number } \\
\text { of companies 50-250 } \\
(1997-2007)\end{array}$ & NoF 249 07/97 & 1.18 & 1.18 & 0.36 & 2.33 & 1.98 & 31.79 \\
\hline $\begin{array}{c}\text { Change in the number } \\
\text { of companies } \\
250+(1997-2007)\end{array}$ & NoF 250+ 07/97 & 0.96 & 0.95 & 0.00 & 2.67 & 2.67 & 58.58 \\
\hline
\end{tabular}

Source: Authors' own processing of data made accessible by the Statistical Office of the Slovak Republic 
MISCELLANEA GEOGRAPHICA - REGIONAL STUDIES ON DEVELOPMENT

Vol. $20 \cdot$ No. $3 \cdot 2016 \cdot$ pp. 5-13 • ISSN: 2084-6118 • DOI: 10.1515/mgrsd-2016-0011

sectors have seen a decrease in the number of companies in the size category of 250 or more employees. In most cases, the breakdown of large companies has led to the decomposition of production capacities (employment, machinery) into small and medium-sized enterprises, especially focused on textile and wearing apparel and metals and machinery equipment. A complete decomposition of large and medium-sized industrial enterprises was observed in the mining of metal ores, food products, wood processing and furniture production sectors. Only seven sectors registered an increase in the number of companies in all size categories.
The restructuring of technology-intensive industrial sectors (e.g. machinery and equipment production) forced Slovak entrepreneurs to change their focus of production or to compete with the new substitutes. Such a step required the cooperation of strategic foreign partners who would invest in innovative technologies and interconnect domestic ownership with foreign ownership. With labour-intensive industrial sectors (e.g. clothing), transformation strategies were realized through foreign coownerships. These aspects of regional industrial changes in the context of global production networks were also highlighted by Smith et al. (2014), who point to the fact that companies active in the

Table 2. The development of sectoral concentration of industrial sectors (Herfindahl-Hirschman concentration index) and difference in the number of companies (NoC) in size categories between1997 and 2007

\begin{tabular}{|c|c|c|c|c|c|c|c|}
\hline \multirow{2}{*}{ code } & \multirow{2}{*}{ Field of economic activity } & \multirow{2}{*}{1997} & \multirow{2}{*}{2007} & \multirow{2}{*}{ 2007/1997 } & \multicolumn{3}{|c|}{ difference NoC 07-97 } \\
\hline & & & & & $0-49$ & $50-249$ & $250+$ \\
\hline 10 & Mining of coal and lignite; extraction of peat & 0.638 & 0.830 & 1.301 & -2 & +4 & -3 \\
\hline 11 & Extraction of crude petroleum and natural gas & 0.989 & 0.926 & 0.936 & 0 & 0 & 0 \\
\hline 13 & Mining of metal ores & 0.346 & 0.820 & 2.371 & -6 & -1 & -1 \\
\hline 14 & Other mining and quarrying & 0.104 & 0.067 & 0.646 & +48 & +4 & -6 \\
\hline 15 & Manufacture of food products and beverages & 0.029 & 0.030 & 1.038 & +113 & -53 & -28 \\
\hline 16 & Manuf. of tobacco products & 1.000 & - & - & 0 & 0 & -1 \\
\hline 17 & Manuf. of textiles & 0.055 & 0.061 & 1.102 & +50 & +9 & -11 \\
\hline 18 & Manuf. of wearing apparel & 0.063 & 0.055 & 0.869 & +161 & +16 & -12 \\
\hline 19 & Tanning and dressing of leather & 0.274 & 0.125 & 0.456 & +51 & -7 & -1 \\
\hline 20 & Manuf. of wood and of products of wood & 0.052 & 0.038 & 0.729 & +547 & -2 & -10 \\
\hline 21 & Manuf. of pulp, paper and paper products & 0.166 & 0.125 & 0.751 & +44 & +10 & -2 \\
\hline 22 & Publishing, printing and reproduction & 0.116 & 0.102 & 0.880 & +311 & -2 & 0 \\
\hline 23 & Manuf. of coke, refined petroleum products & 0.674 & 0.869 & 1.289 & +4 & 0 & -1 \\
\hline 24 & Manuf. of chemicals and chemical products & 0.083 & 0.096 & 1.157 & +73 & +9 & -5 \\
\hline 25 & Manuf. of rubber and plastic products & 0.145 & 0.065 & 0.447 & +289 & +47 & +10 \\
\hline 26 & Manuf. of other non-metallic mineral products & 0.052 & 0.046 & 0.890 & +150 & -5 & -10 \\
\hline 27 & Manuf. of basic metals & 0.210 & 0.290 & 1.379 & +7 & +16 & -4 \\
\hline 28 & Manuf. of fabricated metal products & 0.037 & 0.027 & 0.728 & +900 & +63 & -8 \\
\hline 29 & Manuf.of machinery and equipment n.e.c. & 0.033 & 0.039 & 1.172 & +228 & +12 & -40 \\
\hline 30 & Manuf.of office machinery and computers & 0.405 & 0.222 & 0.548 & +22 & +2 & +1 \\
\hline 31 & Manuf. of electrical machinery and apparel & 0.062 & 0.050 & 0.804 & +138 & +36 & +20 \\
\hline 32 & Manuf. of radio, television and communication & 0.205 & 0.114 & 0.556 & +26 & +4 & +8 \\
\hline 33 & $\begin{array}{l}\text { Manuf. of medical, precision and opt. } \\
\text { instruments }\end{array}$ & 0.233 & 0.160 & 0.684 & +81 & +8 & -7 \\
\hline 34 & Manuf. of motor vehicles, trailers & 0.123 & 0.127 & 1.037 & +47 & +33 & +14 \\
\hline 35 & Manuf. of other transport equipment & 0.157 & 0.144 & 0.913 & +13 & +2 & -2 \\
\hline 36 & Manuf. of furniture; manufacturing n.e.c. & 0.039 & 0.050 & 1.264 & +149 & -5 & -11 \\
\hline 37 & Recycling & 0.170 & 0.381 & 2.240 & +54 & +1 & -3 \\
\hline 40 & Electricity, gas, steam and hot water supply & 0.068 & 0.231 & 3.397 & +136 & +30 & +3 \\
\hline \multirow[t]{3}{*}{41} & $\begin{array}{l}\text { Collection, purification and distribution of } \\
\text { water }\end{array}$ & 0.057 & 0.136 & 2.371 & +18 & +4 & +2 \\
\hline & Total & & & & +3652 & +235 & -108 \\
\hline & Coefficient of variation & 118.298 & 128.445 & & & & \\
\hline
\end{tabular}

Source: Authors' own processing based on data made accessible by the Statistical Office of the Slovak Republic 
clothing industry transferred their export to the western markets of the EU 15. They consider the entry of foreign capital and mixed (shared) foreign and domestic ownership as the main strategic factor breaking down the risk of export dependency.

\section{Regional specialization}

As Table 1 demonstrates, the period of economic restructuring saw a decrease in the average rate of regional specialization (average and median), as well as a decrease in the variability index of specialization in certain regions. This fact corresponds with the development of specialization in Western European countries in the 1980s and 1990s (Hallet, 2000).

A regional insight into the specialization index is provided in Table 3. A decrease in specialization in the period of economic transformation was recognized in almost $60 \%$ of the regions. Out of 20 regions where specialization increased, eight show only a slight increase of less than 0.1. All metropolitan regions (NUTS
II), except from Banská Bystrica, increased their specialization. A significant increase in specialization is also recognised in the metropolitan regions of Bratislava, Košice, Nitra and Trnava.

Table 3 shows the difference in the number of companies in the individual size categories with respect to their spatial distribution. In $71 \%$ of the regions, the number of large companies with more than 250 employees decreased. Transformation strategies for the breakdown of large companies were carried out in various manners. The first transformation strategy followed the direction of establishing small and medium-sized enterprises. $39 \%$ of all regions reached a positive balance in the remaining two size categories. The second transformation strategy of companies meant the divide of medium-sized enterprises (with a negative balance in the size category of $49-250$ employees in only $25 \%$ of the regions), whereas in two regions in Eastern Slovakia (Michalovce and Trebišov), the number of companies did not increase in any size category. Most companies in the 250 or

Table 3. The development of regional specialization of FURs (Herfindahl-Hirschman index specialization) and difference in the number of companies (NoC) in size categories between1997 and 2007

\begin{tabular}{|c|c|c|c|c|c|c|c|c|c|c|c|}
\hline \multirow{2}{*}{ FUR } & \multirow{2}{*}{1997} & \multirow{2}{*}{2007} & \multicolumn{3}{|c|}{ difference NoC 07-97 } & \multirow{2}{*}{ FUR } & \multirow{2}{*}{1997} & \multirow{2}{*}{2007} & \multicolumn{3}{|c|}{ difference NoC 07-97 } \\
\hline & & & $0-49$ & $50-249$ & $250+$ & & & & $0-49$ & $50-249$ & $250+$ \\
\hline $\begin{array}{l}\text { BB - Banská } \\
\text { Bystrica }\end{array}$ & 0.114 & 0.100 & +78 & 0 & -6 & TV - Trebišov & 0.247 & 0.222 & -1 & 0 & -2 \\
\hline PN - Piešt’any & 0.167 & 0.120 & +65 & +6 & +5 & TS - Tvrdošín & 0.715 & 0.231 & +27 & +7 & 0 \\
\hline PD - Prievidza & 0.159 & 0.124 & +102 & +2 & +1 & HC - Hlohovec & 0.279 & 0.233 & +37 & +5 & -2 \\
\hline $\begin{array}{l}\text { DS - Dunajská } \\
\text { Streda }\end{array}$ & 0.158 & 0.125 & +115 & +14 & -1 & $\begin{array}{c}\text { ZH - Žiar nad } \\
\text { Hronom }\end{array}$ & 0.262 & 0.234 & +70 & +17 & -8 \\
\hline $\begin{array}{l}\text { LM - Liptovský } \\
\text { Mikuláš }\end{array}$ & 0.127 & 0.129 & +62 & +14 & -7 & $\begin{array}{c}\text { NM - Nové M.nad } \\
\text { Váh. }\end{array}$ & 0.224 & 0.243 & +105 & +5 & +8 \\
\hline CA-Čadca & 0.168 & 0.133 & +60 & 0 & -3 & BA - Bratislava & 0.211 & 0.244 & +691 & +19 & -8 \\
\hline NR - Nitra & 0.112 & 0.143 & +117 & +15 & -1 & SV - Snina & 0.495 & 0.249 & +29 & +4 & -1 \\
\hline PP - Poprad & 0.245 & 0.144 & +75 & +11 & -3 & SE - Senica & 0.341 & 0.253 & +82 & +12 & -1 \\
\hline SL - Stará L'ubovňa & 0.132 & 0.148 & +25 & -1 & -5 & SI - Skalica & 0.158 & 0.260 & +57 & +4 & -2 \\
\hline DK - Dolný Kubín & 0.268 & 0.151 & -5 & 0 & +3 & $\begin{array}{l}\text { ZM - Zlaté } \\
\text { Moravce }\end{array}$ & 0.580 & 0.288 & +22 & -3 & -2 \\
\hline LV - Levice & 0.192 & 0.163 & +65 & +7 & -4 & $\begin{array}{l}\text { PB - Považská } \\
\text { Bystrica }\end{array}$ & 0.182 & 0.294 & +48 & +9 & -2 \\
\hline TN - Trenčín & 0.157 & 0.169 & +180 & +19 & -4 & GA - Galanta & 0.426 & 0.298 & +152 & +15 & 0 \\
\hline TT - Trnava & 0.104 & 0.173 & +148 & -4 & +1 & ZV - Zvolen & 0.389 & 0.323 & +69 & +6 & +2 \\
\hline KN - Komárno & 0.195 & 0.174 & +77 & +11 & +1 & NO - Námestovo & 0.233 & 0.332 & +18 & +1 & +1 \\
\hline $\begin{array}{l}\text { RS - Rimavská } \\
\text { Sobota }\end{array}$ & 0.204 & 0.175 & +5 & -1 & -3 & HE - Humenné & 0.430 & 0.333 & +26 & -1 & -3 \\
\hline PO - Prešov & 0.170 & 0.175 & +88 & -4 & -18 & RV - Rožňava & 0.325 & 0.335 & -7 & -1 & +1 \\
\hline NZ - Nové Zámky & 0.158 & 0.178 & +90 & +9 & -2 & MI - Michalovce & 0.254 & 0.373 & -7 & 0 & -1 \\
\hline VK - Vel'ký Krtíš & 0.257 & 0.183 & +14 & -1 & -3 & TO - Topol'čany & 0.514 & 0.417 & +89 & -2 & +3 \\
\hline NT - Martin & 0.225 & 0.184 & +87 & +7 & -2 & ZA - Žilina & 0.410 & 0.421 & +180 & +30 & -9 \\
\hline $\begin{array}{c}\text { VT - Vranov nad } \\
\text { Topl'ou }\end{array}$ & 0.210 & 0.185 & +20 & -14 & -3 & RK - Ružomberok & 0.333 & 0.479 & +29 & -1 & -2 \\
\hline PU - Púchov & 0.314 & 0.191 & +28 & +7 & -1 & KO - Košice & 0.407 & 0.486 & +131 & -5 & -7 \\
\hline IL - Ilava & 0.372 & 0.208 & +84 & +14 & +1 & SK - Svidník & 0.481 & 0.519 & +39 & -2 & -2 \\
\hline $\begin{array}{c}\text { BN - Bánovce nad } \\
\text { Beb. }\end{array}$ & 0.276 & 0.216 & +37 & +3 & 0 & LC - Lučenec & 0.497 & 0.534 & +43 & -5 & -3 \\
\hline BJ - Bardejov & 0.450 & 0.217 & +69 & -4 & -3 & BR - Brezno & 0.327 & 0.552 & +18 & 5 & -9 \\
\hline $\begin{array}{c}\text { SN - Spišská Nová } \\
\text { Ves }\end{array}$ & 0.153 & 0.218 & +19 & +2 & -2 & Total & & & +3652 & +235 & -108 \\
\hline
\end{tabular}

Source: Authors' own processing of data made accessible by the Statistical Office of the Slovak Republic 
more employees category left Prešov, followed by the industria regions of Žiar nad Hronom, Žilina, Brezno, Košice, and so on. In the third transformation strategy, the number of companies in the 250 or more employees category increased. This was the case in eleven regions; in seven of these, the number increased in all size categories.

\section{Regional industrial types}

In Table 4, an attempt is made to explain the change in regional specialization between 1997 and 2007, using the initial value of the specialization index in 1997 and the number of companies in the three size categories as independent variables. A simple regression heteroskedasticity corrected model was used, which corrects discrepancies in the variance of change in the number of companies in the three size categories. Heteroskedasticity was declared by the White test. Econometric verification of the model was processed in the Gretl program with the use of the Wald test for autocorrelation, while multicollinearity was tested by variance inflation factors. Finally, the normality of the residuals was tested by the Chi-square test.

The results indicate a significant negative effect of the initial value of regional specialization in 1997 in the size category of 250 or more employees. In the first place, the initial value of the specialization index in 1997 demonstrates the fact that a decrease in regional specialization occurred in regions with a higher specialization index in comparison with other regions at the beginning of the analysed period. This relation can be interpreted by the fact that regional specialization between 1997 and 2007 followed convergence tendencies among the regions. In the second place, the decrease in the specialization index is caused by the growing value of the index of change in the number of companies in the size category of 250 or more employees. Considering the value of coefficient $B$ is close to zero $(-0.022)$, the relationship between the analysed variables is not clear.
Thus, an attempt was made to capture this ambiguous relation in Figure 1 and in a more simplified form in Figure 2.

The results are visualized in Figure 1 and 2, where a typology is created of the regional industrial regions and their transformation strategies. Both explanatory variables were used to fully clarify the changes in the industrial structure of regions in the process of restructuring. In the first step of the identification of regions based on their specialization being low or high, 1997 was chosen as the referential year. The dividing limit was set on the median value in 1997. In the left part of Figure 1A, regions with low specialization are identified, whereas the right part (Figure 1B) shows highly specialized regions. In the second step, the position of individual regions was identified based on the relationship between the change of specialization index and the change in the number of companies in the size category of 250 or more employees between 1997 and 2007. During the restructuring period, four transformation strategies were adopted by regions with low specialization as well as highly specialized regions. Finally, eight regional industrial types were identified, plus one subtype in which the decrease in specialization is not accompanied by a change in the number of large companies.

Figure 2 represents the transformation strategies of individual regions. An increase in the specialization index is expected in regions with low specialization in 1997, along with a decrease in the number of large companies (type A-II 10 regions). This means that only one industrial branch remained in the region, thus resisting restructuring, whereas other branches disappeared. The industrial type with the largest representation across regions also recorded the largest decrease in the size category of 250 or more employees, while at the same time seeing the largest increase in the other two size categories. Type A-I (9 regions) is characterised by a decrease in specialization in regions with low specialization, along with a decrease in the number of large companies. In this case, restructuring struck the relatively dominant industrial

Table 4. Relationships between specialization and size categories of industrial companies

\begin{tabular}{|c|c|c|c|c|c|}
\hline \multicolumn{6}{|c|}{$\begin{array}{l}\text { Heteroskedasticity corrected model } \\
\text { dependent variable: change of specialization index 2007/1997 }\end{array}$} \\
\hline & $\begin{array}{c}\text { Coefficient } \\
\text { ß }\end{array}$ & $\begin{array}{l}\text { Standard } \\
\text { error }\end{array}$ & t-ratio & $p$-value & \\
\hline Level constant & 1.231 & 0.098 & 12.612 & $<0.00001$ & *** \\
\hline Specialization index 1997 & -1.089 & 0.254 & -4.284 & 0.000 & *** \\
\hline $\begin{array}{l}\text { Change in the number of } \\
\text { companies 0-49 2007/1997 }\end{array}$ & 0.000 & 0.000 & 1.303 & 0.199 & \\
\hline $\begin{array}{l}\text { Change in the number of } \\
\text { companies } 50-2492007 / 1997\end{array}$ & -0.006 & 0.005 & -1.283 & 0.206 & \\
\hline $\begin{array}{l}\text { Change in the number of } \\
\text { companies } 250+2007 / 1997\end{array}$ & -0.022 & 0.011 & -2.038 & 0.048 & ** \\
\hline $\mathrm{N}$ & 49 & & & & \\
\hline $\mathrm{R}^{2}$ & 0.575 & Customized $\mathrm{R}^{2}$ & & 0.536 & \\
\hline$F(4,44)$ & 14.857 & P-value(F) & & 0.000 & \\
\hline
\end{tabular}

*** significant at $1 \%$ level, ** significant at $5 \%$ level

Source: Authors' own processing of data made accessible by the Statistical Office of the Slovak Republic 

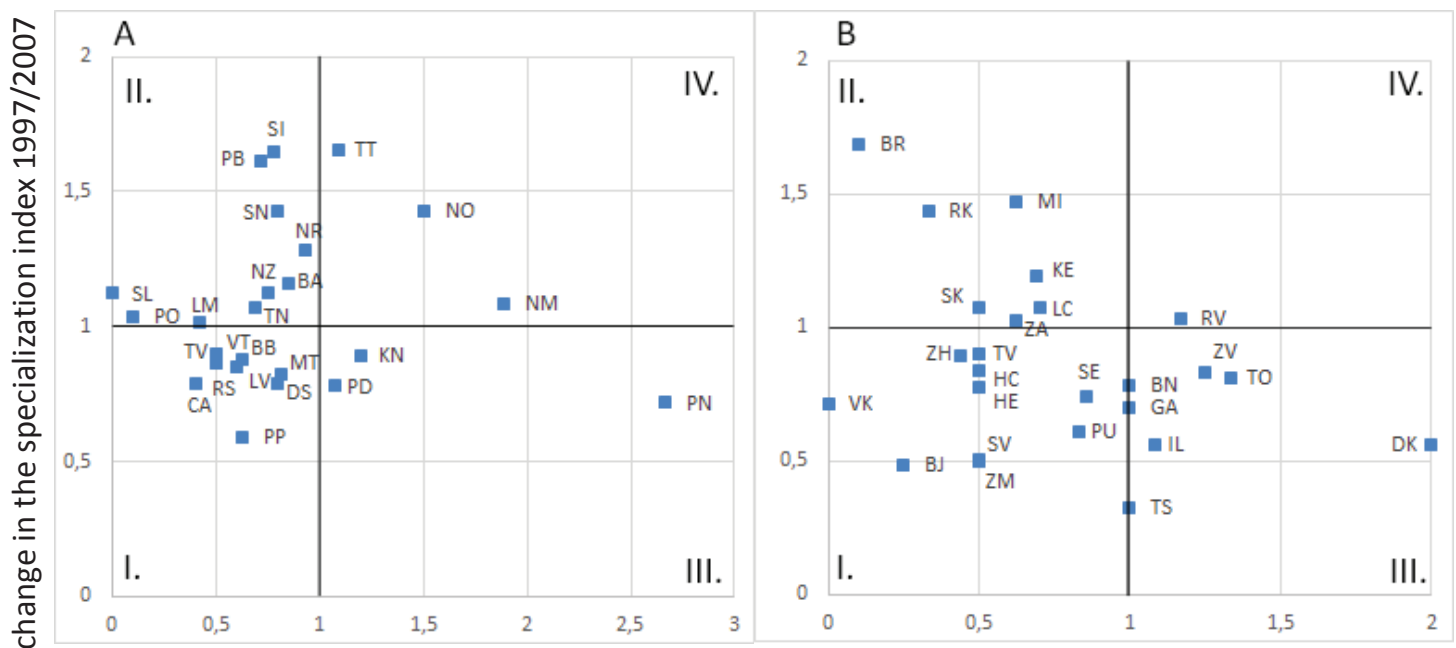

Change in the number of companies in the size category of 250 or more employees

Note: A - Regions with low specialization in 1997, B - highly specialized regions in 1997

Source: Authors' own processing of data made accessible by the Statistical Office of the Slovak Republic

Figure 1. The relationship between change in the specialization index and change in the number of companies in the size category of 250 or more employees

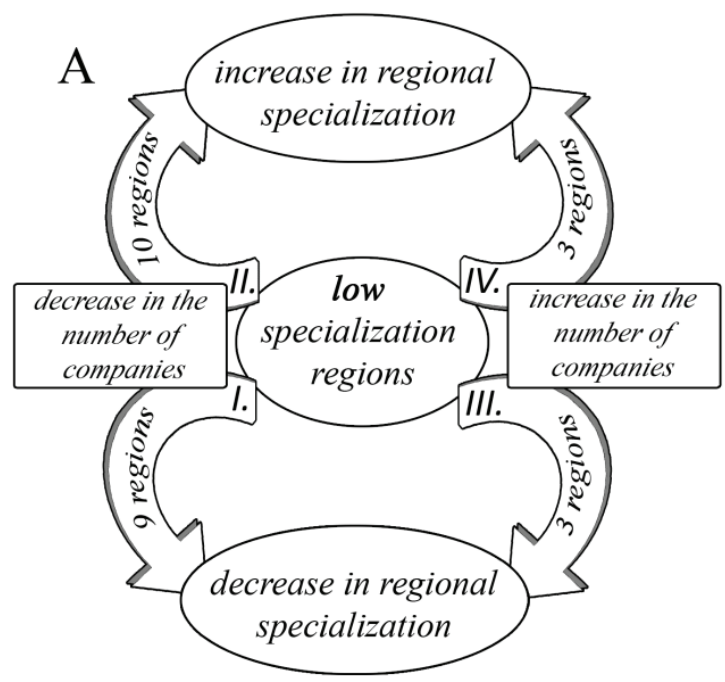

Figure 2. Transformation strategies of the regions

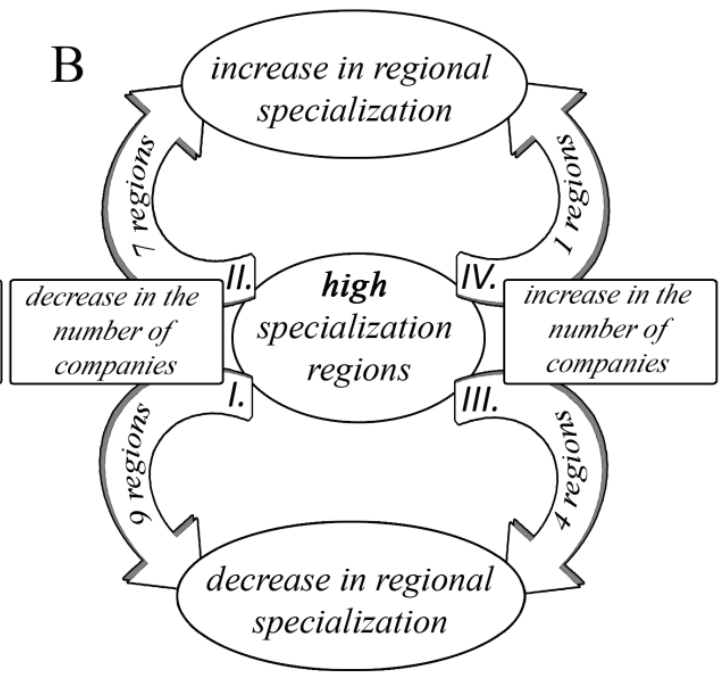

branch in the (originally low-specialized) industrial structure of the region, which had become more diversified. It is this regional type where only a minimal fluctuation in the number of companies in all size categories was manifested. For the regions that were highly specialized in 1997, attention should be paid to the two regional types that followed the same transformation strategies. The first type, B-I (9 regions), is characterised by its expected decrease in the specialization index and the decrease in the number of large companies. In this case, the significance of the absolutely dominant industrial branch decreased in the region, or other branches were supported. Regional industrial type B-II (7 regions) is also interesting, as the regional specialization increased in highly specialised regions, while the number of large companies decreased. This strategy means that regions which used to have a dominant industrial branch strengthened their position in the process of restructuring. Thus, most large companies had to shut down their industrial plants.

\section{Conclusion}

The majority of the academic studies evaluating regional specialization and geographic concentration focus on longterm historical analysis (Midelfart-Knarvik et al. 2003). Although our research emanates from a shorter period of time, we believe that these results are still valid. As a result of privatization, liberalization and regulation, industry has changed significantly over the analysed period in terms of its size and structure (Rehák and Štofko 2011).

The first remark concerns the development of geographic concentration. Differences were observed between industrial sectors in the level of geographic concentration, which deepened 
between 1997 and 2007. Up to $20 \%$ of industrial sectors reached more than 0.25 in the concentration index. This proportion remained the same over the analysed period, whereas geographic concentration decreased significantly in labour-intensive and technology-intensive sectors. On the other hand, an increase in concentration can be seen in traditional (mature) industrial branches (Ezcurra et al. 2006) and new distribution branches.

The second remark concerns regional specialization. The average level of specialization (average and median) decreased. At the same time, the variance of the specialization index decreased. This fact corresponds with the development of regional specialization in Western Europe in the 1980s and 1990s (Hallet, 2000). Regional insight into the specialization index shows that $60 \%$ of the regions recorded a decrease in specialization over time. Additionally, it was observed that all the metropolitan regions, except from Banská Bystrica, increased their specialization between 1997 and 2007 . In $71 \%$ of the regions, a slight decrease in the number of large companies with more than 250 employees was registered.

The descriptive analysis was supported by the regression analysis. The change in the regional specialization is explained by the initial level of regional specialization in 1997 and the size category of 250 or more employees. Both values were negative. In the first place, it can be interpreted that regional specialization between 1997 and 2007 followed the convergence tendencies among the regions. However, although the change in the number of companies appeared to be significant in our model, its values do not clearly define the relationship between the analysed variables. For a better understanding of this ambiguous relationship, graphic visualisation is provided in Figure 1 and 2.

In accordance with the new economic geography, it is supposed that the localization of large industrial companies will be followed by small and medium-sized enterprises in the context of input-output linkages. Bearing this in mind, in the following period the number of companies with 250 or more employees is expected to stabilize, with a simultaneous increase in the influence that small and medium-sized enterprises impose on the change in regional specialization.

Autonomy, interdedendance and interactions of spatial systems" and the Comenius University Grant No. UK/537/2015 "Specialization and concentration as Explanatory Variables of Economic Performance of Slovak Regions.

\section{References}

Aiginger, K \& Davies, SW 2004, 'Industrial specialisation and geographic concentration: two sides of the same coin? Not for the European Union', Journal of Applied Economics, vol. 7, no 2, pp. 231-248.

Baláž, V, Kluvánková-Oravská, T \& Zajac, Š 2007, 'Institutions and economic transformation', Bratislava: Veda.

Beaudry, C \& Schiffauerova, A 2009, 'Who's right, Marshall or Jacobs? The localization versus urbanization debate', Research Policy, vol. 38, pp. 318-337.

Bezák, A2000, 'Functional urban regions in Slovakia', Geographia Slovaca, 15. Bratislava: Geografický ústav SAV.

Bohle, D \&Greskovits, B 2012, 'Capitalist diversity on Europe's periphery'. Ithaca, NY: Cornell University Press.

Brulhart, M \& Traeger, R 2005, 'An Account of Geographic Concentration Patterns in Europe',Regional Science and Urban Economics, vol. 35, no.6, pp. 597-624.

Ezcurra, R, Pascual, E \&Rapun, M 2006, 'The dynamics of industrial concentration in the regions of the European Union', Growth and Change, vol. 37, no.2, pp. 200-229.

Fujita, M, Krugman P \& Venables, A 2001, 'The spatial economy: Cities, regions, and international trade', Cambridge: MIT press.

Fujita, M \& Thisse JF 2009, 'New economic geography: an appraisal on the occasion of Paul Krugman's 2008 Nobel Prize in Economic Sciences.' Regional Science and Urban Economics, vol. 39, no. 2, pp. 109-119.

Hallet, M 2000, 'Regional specialisation and concentration in the EU', In CuadradoRoura, J. (ed.), Regional convergence in the European Union: Facts, prospects and policies, Berlin: Springer, pp. 53-76.

Konyova, V \& Bartova, L 2013, 'Specialization and Determinants of Geographic Concentration Pattern of the Slovakia Economic Sectors', The International Scientific Conference INPROFORUM, pp. 109-114.

Krugman, P 1991, 'Geography and Trade', Cambridge: MIT Press.

Lane, D \& Myant, M 2007, 'Varieties of Capitalism in PostCommunist Countries', Basingstoke: Palgrave-Macmilan.

Melíšek, V, 2008, 'Approaches to Measurement and Quantification of Structural Changes in Economy',Ekonomický časopis, vol. 56 , no. 1 , pp. 53-71.
Midelfart-Knarvik, KH, Overman, FG, Redding, SJ \& Venables AJ 2003, «The Location of European Industry), In Dierx, A, Ilzkovitz, F, Sekkat, K. eds., European Integration and the Functioning of Product Markets. Cheltenham: Edward Elgar, pp. 213-270.

Mládek, J 1995,'The process of transformation of the Slovak Industry', Geographia Slovaca, vol. 10, pp. 163-172.

Morvay, K 2005, 'Strategy and History of Economic Transformation in Slovakia', Ekonomický časopis, vol. 53, no. 1, pp. 5-32.

Nölke, A \& Vliegenthart, A 2009, 'Enlargingthe Varieties of Capitalism: The Emergence of Dependent Market Economies in East Central Europe', World Politics, vol. 61, no. 4, pp. 670-702.

Osiński, S 2004, 'Changes in Poland's industry after 1989' Miscellanea Geographica, vol. 11, pp. 249-261.

Parysek, JJ \& Stryjakiewicz, T 2000, 'Polish economy in transition: spatial perspectives', Poznań: Bogucki-Wydawnictwo Naukowe.

Pavlínek, P 2002, 'Selected Theoretical Interpretations of the Contemporary Transition of Capitalism ', Politická Ekonomie, vol. 50, no.5, pp. 717-732.

Pickles, J. \& Smith, A., 1998, 'Theorising Transition: The Political Economy of Post-Communist Transformations', London: Routledge.

Rusnák, J \& Korec, P 2013, 'An Alternative Conceptions of Post-socialist Transformation' Ekonomický časopis, vol. 61, no. 4 , pp. 396-418.

Rehák, Š \& Štofko, M 2011, 'Structural changes of Slovak regions: regional specialisation and spatial concentration', Regional direct, vol. 4, no. 2, pp. 4-23.

Smith, A 1998, 'Reconstructing the regional economy: Industrial transformation and regional development in Slovakia', Cheltenham: Edward Elgar Publishing.

Smith, A, Pickles, J, Buček, M, Pástor, R \& Begg, B 2014, 'Thepolitical economy of global production networks: regional industrial change and differential upgrading in the East European clothing industry', Journal of Economic Geography, vol. 14, no. 6, pp. 1023-1051.

Sokol, M 2001. 'Central and Eastern Europe a Decade After the Fall of State-socialism: Regional Dimensions of Transition Processes', Regional Studies, vol. 35, no.7, pp. 645-655. 
Stark, D \& Brurszt, L 1998, 'Postsocialist Pathways, Transfonning Politics and Property in East Central Europe', Cambridge: Cambridge University Press.

Traistaru, I, Nijkamp, P \&S. Longhi. 2003, 'Specialization of regions and concentration of industries in EU accession countries' InTraistaru I, Nijkamp P, \& Resmini L, The emerging economic geography in EU accession countries, Aldershot, UK: Ashgate, pp, 331-371.

Vojtková, M \& Kvetan, V 2011, 'Regional Analysis of the Industry in Slovakia According to Selected Indicators',Ekonomický časopis, vol. 57, no. 9, pp. 870-890.
Wandel, C 2010, 'Industry Agglomerations and Regional Development in Hungary: Economic Processes During European Integration', Peter Lang, vol. 42.

Ženka, J, Novotný, J, Slach, O \& Květoň, V 2015, 'Industrial specialization and economic performance: a case of Czech microregions' Norwegian Journal of Geography, vol. 69, no. 2, p. 67-79. 